\title{
Pharmacognosy \\ Phytochemical analysis and hypotensive activity of Ipomoea pes-caprae on blood pressure of normotensive rats
}

\author{
Fernanda Manhães Braga Gonçalves ${ }^{1,3,4}$, Amaro Chaves Ramos ${ }^{1}$, Marcelo da Silva Mathias ${ }^{1}$, \\ Queitilane de Souza Sales ${ }^{1}$, Carolina Chaves Ramos ${ }^{1}$, Fernanda Antunes ${ }^{2}$ \& Rodrigo Rodrigues de Oliveira ${ }^{1}$
}

\begin{abstract}
Ipomoea pes-caprae (Convolvulaceae), popularly known as "salsa-da-praia", is used in folk medicine for the treatment of several diseases, including hypertension. The aim of this research was to evaluate hypotensive activity attributed to this species and identify the bioactive compounds responsible for this effect. Hydroalcoholic extract of aerial parts of Ipomoea pes-caprae (PIEA) was fractionated by column chromatography with Amberlite XAD-2, thus achieving a methanolic fraction (PIEA-M). The chemical profile investigation of PIEA-M was conducted by Ultra Performance Liquid Chromatography coupled to Mass Spectrometry (UPLC-MS) and compound isolation through High Performance Countercurrent Chromatography (HPCCC). Hemodynamic evaluations of PIEA, PIEA-M and isolated compounds were carried out on normotensive rats. The locomotor activity of PIEA and PIEA-M were performed by Rota Rod test using Swiss mice. UPLC-MS analysis of PIEA-M led to the identification of 11 compounds corresponding to seven phenolic acids and four flavonoids. By means of HPCCC, quercetin 6"-O-acetyl-3- $O$ - glucoside (1), a mixture of quercetin-3$O$-galactoside and quercetin-3-O-glucoside (2) and quercetin 3-O-glucoside (3) were isolated. PIEA, PIEA-M and the obtained compounds (1 and 2) significantly reduced blood pressure. Also, PIEA and PIEA-M caused significant impairment on mice locomotor activity. These results indicate the potential of Ipomoea pes-caprae as a source of hypotensive agents suggesting that phenolic compounds present in the species are responsible for its hypotensive activity. Key words: Convolvulaceae, hypertension, Ipomoea pes-caprae, phenolic compounds, rota-rod.

\section{Resumo}

Ipomoea pes-caprae (Convolvulaceae), conhecida popularmente como "salsa-da-praia", é usada na medicina popular para o tratamento de várias doenças, incluindo a hipertensão. O objetivo desta pesquisa foi avaliar a atividade hipotensora atribuída a essa espécie e identificar os compostos bioativos responsáveis por esse efeito. O extrato hidroalcoólico das partes aéreas de Ipomoea pes-caprae (PIEA) foi fracionado por cromatografia em coluna com Amberlite XAD-2, obtendo-se uma fração metanólica (PIEA-M). A investigação do perfil químico de PIEA-M foi realizada por Cromatografia :íquida de Ultra-Eficiência acoplada a Espectrometria de Massas (CLUE-EM) e isolamento de compostos por Cromatografia Contracorrente de Alto Desempenho (CCCAD). Avaliações hemodinâmicas dos PIEA, PIEA-M e compostos isolados foram realizadas em ratos normotensos. A atividade locomotora de PIEA e PIEA-M foi realizada pelo teste de Rota Rod usando camundongos suíços. A análise CLUE-EM do PIEA-M levou à identificação de 11 substâncias correspondentes a sete ácidos fenólicos e quatro flavonoides. Por meio de CCCAD, a quercetina 6"-O-acetil-3-O-glicosídeo (1), uma mistura de quercetina-3-O-galactosídeo e quercetina-3-O-glicosídeo (2) e quercetina 3-O-glicosídeo (3) foram isolados. PIEA, PIEA-M e as substâncias obtidas (1 e 2) reduziram significativamente a pressão sanguínea. Além disso, o PIEA e o PIEA-M causaram um prejuízo significativo na atividade locomotora dos camundongos. Estes resultados indicam o potencial de Ipomoea pes-caprae como fonte de agentes hipotensores, sugerindo que os compostos fenólicos presentes na espécie são responsáveis por sua atividade hipotensora.
\end{abstract}

Palavras-chave: Convolvulaceae, hipertensão, Ipomoea pes-caprae, compostos fenólicos, rota-rod.

\footnotetext{
${ }^{1}$ Universidade Estadual do Norte Fluminense Darcy Ribeiro, Centro de Ciência e Tecnologia, Lab. Ciências Químicas, Av. Alberto Lamego 2000, 28013-602, Campos dos Goytacazes, RJ, Brasil.

${ }^{2}$ Universidade Estadual do Norte Fluminense Darcy Ribeiro, Centro de Ciências e Tecnologias Agropecuárias, Lab. Clínica e Cirurgia Animal, Av. Alberto Lamego 2000, 28013-602, Campos dos Goytacazes, RJ, Brasil.

${ }^{3}$ ORCID: < https://orcid.org/0000-0001-5066-5738>

${ }^{4}$ Author for correspondence: fernandinha.mbraga@gmail.com
} 


\section{Introduction}

Natural products play an important role in the pharmaceutical industry, providing many active substances used to treat several diseases (Berlinck et al. 2017). In this sense, the popular knowledge significantly contributes to the development of new medicines (Viegas \& Bolzani 2006). Last surveys about new drug sources, conducted between 1981 and 2014, showed most medicines derive from natural products (Newman \& Cragg 2016). 122 compounds used as medicines were obtained from 94 plant species, and $80 \%$ of these plants have been used in folk medicine for the same purpose (Fabricant \& Farnsworth 2001).

Hypertension is a disease affecting one billion people worldwide (World Health Organization 2013) and is the main risk-factor for emergency cardiovascular-related episodes such as stroke, peripheral arterial disease, renal and heart failures (Kannel 2000). High blood pressure complications accounts for 9.4 million deaths per year higher than cancer-related deaths per year (World Health Organization 2013, 2017). Hypertension is asymptomatic in the early stage and many people are undiagnosed. Those who are diagnosed may not be able to accomplish a successful long-term disease control. In most cases, the anti-hypertensive therapy changes, doing so that the patient inevitably needs to use two or more drugs to achieve the desirable effect (World Health Organization 2013).

Ipomoea pes-caprae (L.) R. Br. (Convolvulaceae) is used in folk medicine for the treatment of hypertension. This species is popularly known as "salsa-da-praia" and is usually found in coastal dunes of tropical and subtropical regions (Lorenzi \& Matos 2002; Barni et al. 2009; Miryeganeh et al. 2014). In Brazil, this plant is spread throughout the coastal region. Besides hypertension, ethnopharmacological surveys describe several medicinal utilizations of this plant such as: analgesic, anti-inflammatory, diuretic, and healing cramps, ulcers, dermatitis caused by jellyfish venom, arthritis and rheumatism (Wasuwat 1970; Souza et al. 2000; Lorenzi \& Matos 2002; Pereda-Miranda et al. 2005; Barni et al. 2009).

Phytochemical profile of Ipomoea pescaprae is characterized by the presence of glycosidic resins, coumarins, steroids, flavonoids and triterpenes (Krogh et al. 1999; Pereda-Miranda et al. 2005; Teramachi et al. 2005; EscobedoMartínez et al. 2010; Yu et al. 2011; Banerjee et al. 2013; Sharmin et al. 2013). Ipomoea flavonoids are mainly quercetin derivatives which are known for possessing anti-hypertensive activity (Krogh et al. 1999; Loizzo et al. 2008; Barni et al. 2009; Larson et al. 2010). Considering the utilization of this plant in folk medicine as antihypertensive and the need of new anti-hypertensive drugs, the aim of the present study was to evaluate the hemodynamic effects of Ipomoea pes-caprae hydroalcoholic extract, fractions and isolated substances.

\section{Materials and Methods}

General experimental procedure

UPLC-ESI-MS analyses were performed on a Shimadzu LC-20A UPLC instrument (Shimadzu, Kyoto, Japan) equipped with a degasser, a binary pump, an automatic sampler, a column oven and a diode array detector (DAD). The system was coupled to a high resolution mass spectrometer equipped with an electrospray ion source (ESI) and quadrupole time-of-flight mass analyzer (Q-TOF) (Bruker Daltonics, Bremen, Germany). Chromatograms were recorded and processed by LC Solution 1.25 by Shimadzu and the LC/MS system was controlled by HyStar 3.2 software (Bruker Daltonics, Bremen, Germany).

The High Performance Countercurrent Chromatography (HPCCC) was acquired on a Dynamic Extractions Spectrum HPCCC (Berkshire, UK) equipped with a $142 \mathrm{~mL}$ multilayer coil columns (1.6 $\mathrm{mm}$ i.d.). The $\beta$-value ranges from 0.52 to 0.86 and revolution speed can be set up to 1,600 rpm. The system comprises two Knauer Smartline 100 V5010 pumps, a Knauer Smartline 2500 V7604 UV absorbance detector, a Büchi C-660 fraction collector, a LabTech Smart H-150-1500 chiller and a HiChrom 5 mL manual injection valve. The solvent system comprising chloroform: butanol: methanol: water $(7: 3: 3: 4 ; \mathrm{v} / \mathrm{v})$ was chosen by the shake-flask method as described by Berthod \& Carda-Broch (2004).

The NMR spectra were recorded on a Bruker DPX-500 operating at $500 \mathrm{MHz}$ to ${ }^{1} \mathrm{H}$ and $125 \mathrm{MHz}$ to ${ }^{13} \mathrm{C}$. Dissolution of the samples was made with Deuterated dimethyl sulfoxide (DMSO-d6 purity $>99.9 \%$ ), contains $0.1 \% \mathrm{v} / \mathrm{v}$ TMS.

The column chromatography (at atmospheric pressure) was conducted with XAD-2 (tyrenedivinylbenzene copolymer) in a glass column with $90 \times 3 \mathrm{~cm}$ (length $\times$ internal diameter). The TLC analyses were performed by using Merck $\mathrm{GF}_{254}$ silica gel 60 revealed by different chemical and physical methods. 
The hemodynamic parameters were measured using Bioamp7 equipment (Adinstrumentes, Australia) and GraphLab software (version 7.0; $\mathrm{AD}$ Instruments). Evaluation of motor coordination was conducted with a Rota Rod instrument (EFF 411, $\left.\operatorname{Insight}^{\circledR}\right)$.

\section{Chemicals}

HPLC-grade formic acid, acetonitrile and methanol were purchased from TEDIA. Water was purified using a Sartorius Arium ${ }^{\circledR}$ mini system. Deuterated dimethyl sulfoxide (DMSO-d6 purity $>99 \%$ ) was purchased from Sigma-Aldrich. Other chemical reagents were purchased from SYNTH. Isoflurane and diazepam $\left(5 \mathrm{mg} \cdot \mathrm{mL}^{-1}\right)$ were purchased from Cristália, heparin $\left(5,000 \mathrm{UI} \cdot \mathrm{mL}^{-1}\right)$ from Blaú-Cristal Pharma and sodium chloride solutions ( $\mathrm{NaCl} 0.9 \%$ ) was obtained from Sanobiol.

\section{Animals}

In vivo tests were performed on male, albino, normotensive Wistar rats (Rattus norvegicus) weighing between 200-300 g and male, albino Swiss mice (Mus musculus) weighing between 25 and $30 \mathrm{~g}$. Animals were kept in plastic cages with controlled temperature $\left(22 \pm 2{ }^{\circ} \mathrm{C}\right)$ and with light and dark light cycles of 12 hours with water and food ad libitum. The present study was approved by UENF's Ethics Committee for Animal Use (CEUA) registered under protocol number 294, and approved on December $15^{\text {th }}$ of 2015.

\section{Plant material}

Aerial parts (leaves and stems) of Ipomoea pes-caprae were collected in Grussaí beach (São João da Barra, Rio de Janeiro, Brazil) in July 2016, under the geographical coordinates $21^{\circ} 41^{\prime} 37.2^{\prime \prime} \mathrm{S}$ and $41^{\circ} 01$ '29.9"W. A voucher specimen (H9793) was deposited at UENF's herbarium. SisGen number: AC4650E.

\section{Extraction and fractionation}

The aerial parts $(100 \mathrm{~g})$ were extracted with $350 \mathrm{~mL}$ of ethanol: water $(1: 1, \mathrm{v} / \mathrm{v})$ in orbital shaker with controlled rotation $(135 \mathrm{rpm})$ and temperature $\left(40{ }^{\circ} \mathrm{C}\right)$. The solvent was changed every 24 hours for 10 days. The obtained solutions were filtered, concentrated in a rotary evaporator under reduced pressure, and subsequently lyophilized to obtain a completely dried extract (PIEA, $30 \mathrm{~g}$ ). An aliquot of this extract $(20 \mathrm{~g})$ was fractionated through XAD2 Amberlite $^{\circledR}$ column eluted with distilled water and, then, eluted with methanol, thus obtaining a methanolic fraction (PIEA-M - $6.82 \mathrm{~g}$ ).

\section{UPLC-ESI-MS and MS/MS analyses}

The PIEA-M was analyzed by UPLC-ESIMS in order to determine the phytochemical profile and identify phenolic compounds. The separation was performed on a C-18 Zorbax column $(1.7 \mu \mathrm{m}$, $2.1 \times 75 \mathrm{~mm}$, Phenomenex). The mobile phase consisted of ultra pure water containing $0.1 \%$ formic acid (A) and acetonitrile containing $0.1 \%$ formic acid (B). The following gradient elution program was determined after several optimization procedures: $0-2 \min 2.5 \% \mathrm{~B}, 2-25 \min 2.5$ to $9.5 \%$ $\mathrm{B}, 25-55 \mathrm{~min}$ maintained at $9.5 \% \mathrm{~B}, 55-60 \mathrm{~min} 9.5$ to $9.6 \% \mathrm{~B}, 60-85 \min 9.6$ to $11 \% \mathrm{~B}, 85-110 \mathrm{~min}$ 11 to $15 \% \mathrm{~B}, 110-140$ min 15 to $25 \% \mathrm{~B}, 140-145$ min 25 to $100 \% \mathrm{~B}, 145-150 \mathrm{~min}$ kept at $100 \% \mathrm{~B}$, $150-155$ min from 100 to $2.5 \% \mathrm{~B}, 155-160 \mathrm{~min}$ $2.5 \% \mathrm{~B}$. The flow rate was maintained at 0.25 $\mathrm{mL} \cdot \mathrm{min}^{-1}$, the column temperature was adjusted to $40^{\circ} \mathrm{C}$, and the injection volume was of $10 \mu \mathrm{L}$. The UV/DAD detector was monitored at $220 \mathrm{~nm}$ (for phenolic acids and flavan-3-ol) and $345 \mathrm{~nm}$ (for flavonoids). The column effluent was introduced into the mass spectrometer at $0.25 \mathrm{~mL} \cdot \mathrm{min}^{-1}$.

The nebulizer gas was high-purity nitrogen $\left(\mathrm{N}_{2}\right)$, produced online by a Peak Scientific NM32LA nitrogen generator. Analysis parameters were set using negative ionization mode with spectra acquired over a mass range from $\mathrm{m} / \mathrm{z} 50$ to 1,400. Optimum ESI-MS parameters were: capillary voltage, $+3.5 \mathrm{kV}$; drying gas temperature, $210^{\circ} \mathrm{C}$; drying gas flow, $10 \mathrm{~L} \cdot \mathrm{min}^{-1}$; nebulizing gas pressure, 72.5 psi; collision RF, $200 \mathrm{Vpp}$; transfer time $120 \mu \mathrm{s}$; and pre-pulse storage, $3 \mu \mathrm{s}$. In addition, automatic MS/MS experiments were performed adjusting the collision-energy values as follows: $\mathrm{m} / \mathrm{z} 500,30 \mathrm{eV} ; \mathrm{m} / \mathrm{z}$ 1,000, $50 \mathrm{eV} ; \mathrm{m} / \mathrm{z}$ 1,400, 70 $\mathrm{eV}$; and using nitrogen as collision gas. MS data were processed through Data Analysis 4.0 software (Bruker Daltonics, Bremen, Germany). External instrument calibration was performed using a Cole Palmer syringe pump (Vernon Hills, IL, USA) directly connected to the interface, eluting a sodium formate $\left(\mathrm{NaCHO}_{2}\right)$ solution cluster containing 5 $\mathrm{mM}$ sodium hydroxide $(\mathrm{NaOH})$ and $0.2 \%$ formic acid in water:isopropanol 1:1 (v/v).

\section{HPCCC separation procedure}

The PIEA-M was subjected to HPCCC using a solvent system comprising chloroform: butanol: methanol: water $(7: 3: 3: 4 ; \mathrm{v} / \mathrm{v})$. The 
HPCCC column was entirely filled with the stationary phase (upper phase). The lower phase (mobile phase) was pumped at a flow rate of 1.5 $\mathrm{mL} \cdot \mathrm{min}^{-1}$ from the head-to-tail direction while the column was rotated at $1,100 \mathrm{rpm}$. After reaching hydrodynamic equilibrium, stationary phase's retention was measured (76.7\%) and $457.9 \mathrm{mg}$ of sample was injected and the eluate collected in $2.5 \mathrm{~mL}$ fractions. These fractions were pooled according to similarity of their chromatographic profiles by TLC in 35 fractions. Fractions 10 (PIEA-M-1-10-Compound 1), 18 (PIEA-M-1-18Compounds 2a and 2b) and 19 (PIEA-M-1-19 Compound 3 , identical to $2 b$ ) were evaluated by NMR experiments.

Spectral data of isolated compounds Compound 1: ${ }^{1} \mathrm{HNMR}\left(500 \mathrm{MHz}, \mathrm{DMSO}-\mathrm{d}_{6}\right)$ : 7.53 (m, H-6'), 7.53 (m, H-2'), 6.84 (d, $J=9.1$ Hz, H-5'), 6.42 (d, $J=1.9 \mathrm{~Hz}, \mathrm{H}-8), 6.21$ (d, $J$ $=1.9 \mathrm{~Hz}, \mathrm{H}-6), 5.38$ (d, $J=7.4 \mathrm{~Hz}, \mathrm{H}-1$ "), 4.13 (dd, $J=11.8,2.0 \mathrm{~Hz}, \mathrm{H}-6$ "a), 3.94 (dd, $J=11.5$, $6.0 \mathrm{~Hz}, \mathrm{H}-6$ " $\mathrm{b}), 1.73\left(\mathrm{~s}, 3 \mathrm{H}, \mathrm{CH}_{3} \mathrm{COO}^{-}\right) .{ }^{13} \mathrm{C} \mathrm{NMR}$ (125 MHz, DMSO-d $)$ : 157.0 (C-2), 133.6 (C-3), 177.8 (C-4), 161.7 (C-5), 99.1 (C-6), 164.6 (C7), 94.0 (C-8), 156.8 (C-9), 104.3 (C-10), 121.5 (C-1'), 116.6 (C-2'), 145.3 (C-3'), 149.0 (C-4'), 115.6 (C-5'), 122.0 (C-6'), 101.4 (C-1'), 74.4 (C2"), 76.7 (C-3"), 70.2 (C-4"), 74.1 (C-5"), 63.2 $(\mathrm{C}-6 "), 170.3\left(-\mathrm{OCOCH}_{3}\right), 20.6\left(-\mathrm{OCOCH}_{3}\right)$. This fraction was identified as quercetin 6"- $O$-acetyl3-O-glucoside (Deepralard et al. 2009).

Compound 2: Compound 2a: ${ }^{1} \mathrm{H}$ NMR (500 MHz, DMSO-d ${ }_{6}$ ): 7.67 (d, $J=8.2$ Hz, H-6'), 6.86 (m, H-2'), 7.6 7(d, J=8.2 Hz, H-5'), 6.41 (s, H-8), 6.21 (s, H-6), 5.38 (d, J=7.4 Hz, H-1"), 3.34 (m, H-6"a), 3.50 (m, H-6"b). ${ }^{13} \mathrm{C}$ NMR (125 MHz, DMSO-d $)$ : 156.8 (C-2), 133.8 (C-3), 177.9 (C-4), 161.7 (C-5), 99.2 (C-6), 164.7 (C-7), 94.0 (C-8), 156.8 (C-9), 104.4 (C-10), 121.6 (C-1'), 115.7 (C2'), 145.3 (C-3'), 148.9 (C-4'), 116.7 (C-5'), 122.1 (C-6'), 102.3 (C-1"), 71.7 (C-2”), 73.7 (C-3”), 68.4 (C-4"), 76.3 (C-5"), 60.6 (C-6"). Compound 2b: 'H NMR (500 MHz, DMSO-d $)$ ) 7.67 (d, $J$ $\left.=8.2 \mathrm{~Hz}, \mathrm{H}-6^{\prime}\right), 6.86$ (m, H-2'), 7.58(m, H-5'), 6.41 (s, H-8), ), 6.21 (s, H-6), 5.47 (d, $J=7.5$ Hz, H-1"), 3.36 (m, H-6" a), 3.65 (m, H-6" b). ${ }^{13} \mathrm{C}$ NMR (125 MHz, DMSO-d ${ }_{6}$ ): 156.7 (C-2), 134.0 (C-3), 178.0 (C-4), 161.7 (C-5), 99.2 (C-6), 164.7 (C-7), 94.0 (C-8), 156.3 (C-9), 104.4 (C-10), 121.6 (C-1'), 115.7 (C-2'), 145.3 (C-3'), 148.9 (C-4'), 116.4 (C-5'), 122.5 (C-6'), 101.4 (C-1'), 74.5 (C2"), 77.0 (C-3"), 70.4 (C-4"), 78.0 (C-5"), 60.8
(C-6"). This fraction was identified as a mixture of quercetin-3-O-galactoside (Coumpound 2a) and quercetin-3-O-glucoside (Compound 2b) (Agrawal 1989).

\section{Hemodynamic evaluation}

Normotensive Wistar rats were anesthetized by inhalation with isoflurane. The left carotid artery of the animals was cannulated to allow the measurement of systolic, diastolic and mean blood pressure. The right jugular vein was also cannulated to allow intravenous sample administration. Cannulas were heparinized with a sodium heparin solution in $0.9 \%$ sodium chloride solution in order to avoid blood clotting. The samples (PIEA, PIEA-M, compounds 1 and 2) were administrated at $30 \mathrm{mg} \cdot \mathrm{kg}^{-1}$ diluted in DMSO with a volume of $0.1 \mathrm{~mL}$ per animal. Prior to the tests, $100 \mu \mathrm{L}$ of DMSO alone was injected as a control of hemodynamic conditions to eliminate the hypotensive effects of DMSO on the results.

\section{Rota-Rod test}

Swiss mice were previously tested on the rotating bar. Those who fell two or more times in a three-minute period were discarded. After animals selection, samples (PIEA and PIEA-M) and diazepam positive control were administered intraperitoneally at $30 \mathrm{mg} \cdot \mathrm{kg}^{-1}$ concentration in $0.1 \mathrm{~mL}$ of DMSO. Each individual was placed with all four legs on a rotating bar already in motion $(20 \mathrm{rpm})$. The mice were observed at the times of 15, 30, 60 and 120 min after sample administration and remained on the rotating bar for three minutes. The number of falls during the three-minute interval was counted.

\section{Statistical analysis}

Results of hemodynamic evaluation were tabulated by LabChart 7 and statistically analyzed through Graphpad Prism 5 software. All obtained data were corrected by Bartlett test. Variables obtained were statistically compared by means of parametric tests, among moments within the groups and among groups by analysis of variance (ANOVA) followed by Newman Keuls multiple comparison test. Student's t-test was also used. For the Rota-Rod test, the results were also statistically analyzed through Graphpad Prism 5 and analysis the variance was performed, followed by Newman Keuls test and Bonferroni means comparison. A 95\% confidence interval was established $(\mathrm{p}<0.05)$. 


\section{Results and Discussion}

Fractionation, identification and isolation

The fractionation of the hydroalcoholic extract using XAD- 2 was performed to concentrate free sugars in the aqueous fraction and phenolic compounds in methanolic fraction. Table 1 summarizes the identified compounds in methanolic fraction by means of molecular formula and MS/MS fragments with their relative abundance. The compounds were identified (Fig. 1) by comparison of fragmentation profiles with literature data and identified as phenolic acids and heterosyl flavonols (Fig. 2).

Table 1 - Phenolic compounds identified in the methanolic fraction of Ipomoea pes-caprae by Ultra Performance Liquid Chromatography coupled with a diode array detector and Mass Spectrometry. Mass Spectrometer equipped with an electrospray ion source (ESI) and quadrupole time-of-flight mass analyzer (Q-TOF). Anaytical conditions of UPLC: same conditions of Figure 1. Analytical conditions of ESI-MS: ionization mode: negative; spectra acquired over a mass range from m/z 50 to 1400 ; capillary voltage: $+3.5 \mathrm{kV}$; drying gas temperature: $210{ }^{\circ} \mathrm{C}$; drying gas flow: $10 \mathrm{~L} \cdot \mathrm{min}^{-1}$; nebulizing gas pressure: $72.5 \mathrm{psi}$; collision RF: $200 \mathrm{Vpp}$; transfer time: $120 \mu \mathrm{s}$; pre-pulse storage: $3 \mu \mathrm{s}$; collision-energy values: $m / z$ 500, $30 \mathrm{eV} ; \mathrm{m} / \mathrm{z} 1000,50 \mathrm{eV} ; \mathrm{m} / \mathrm{z} 1400,70 \mathrm{eV}$; collision gas: nitrogen.

\begin{tabular}{|c|c|c|c|c|c|c|c|c|c|}
\hline Peak & $\begin{array}{c}\mathrm{RT} \\
(\mathrm{min})\end{array}$ & $\begin{array}{r}\lambda_{\text {máx }} \\
(\mathbf{n m})\end{array}$ & {$[\mathbf{M}-\mathbf{H}]^{-}$} & $\begin{array}{l}\text { Theoretical } \\
\text { mass }(m / z)\end{array}$ & $\begin{array}{l}\text { Error } \\
\text { (ppm) }\end{array}$ & $\begin{array}{c}\text { Molecular } \\
\text { formula }\end{array}$ & $\begin{array}{l}\text { MS/MS (\% } \\
\text { abundance) }\end{array}$ & Compound & References \\
\hline 1 & 7.5 & $\begin{array}{l}216 \\
324\end{array}$ & 353.0897 & 353.0878 & 5.38 & $\mathrm{C}_{16} \mathrm{H}_{18} \mathrm{O}_{9}$ & $\begin{array}{l}191(100), 179 \\
(36), 135(65)\end{array}$ & $\begin{array}{l}\text { 3-O-Caffeoylquinic } \\
\text { acid }\end{array}$ & $\begin{array}{c}\text { Jaiswal et } \\
\text { al. } 2014\end{array}$ \\
\hline 2 & 11.9 & $\begin{array}{l}217 \\
322\end{array}$ & 179.0335 & 179.0349 & -7.82 & $\mathrm{C}_{9} \mathrm{H}_{8} \mathrm{O}_{4}$ & $135(100)$ & Caffeic acid & $\begin{array}{l}\text { Santos et al. } \\
\quad 2014\end{array}$ \\
\hline 3 & 13.7 & $\begin{array}{l}217 \\
324\end{array}$ & 353.0899 & 353.0878 & 5.95 & $\mathrm{C}_{16} \mathrm{H}_{18} \mathrm{O}_{9}$ & $191(100)$ & $\begin{array}{l}\text { 5-O-Caffeoylquinic } \\
\text { acid }\end{array}$ & $\begin{array}{l}\text { Jaiswal et } \\
\text { al. } 2014\end{array}$ \\
\hline 4 & 15.6 & $\begin{array}{l}217 \\
325\end{array}$ & 353.0898 & 353.0878 & 5.66 & $\mathrm{C}_{16} \mathrm{H}_{18} \mathrm{O}_{9}$ & $\begin{array}{c}191(100), 135 \\
(76), 173(61), \\
179(57)\end{array}$ & $\begin{array}{l}\text { 4-O-Caffeoylquinic } \\
\text { acid }\end{array}$ & $\begin{array}{l}\text { Ncube et al. } \\
2014\end{array}$ \\
\hline 5 & 37.7 & $\begin{array}{l}254 \\
351\end{array}$ & 463.0881 & 463.0882 & -0.22 & $\mathrm{C}_{21} \mathrm{H}_{20} \mathrm{O}_{12}$ & $300(100)$ & $\begin{array}{c}\text { quercetin } \\
\text { 3-O-galactoside }\end{array}$ & $\begin{array}{l}\text { Santos et al. } \\
\text { 2014; Zhao } \\
\text { et al. } 2017\end{array}$ \\
\hline 6 & 41.5 & $\begin{array}{l}254 \\
359\end{array}$ & 463.0887 & 463.0882 & 1.08 & $\mathrm{C}_{21} \mathrm{H}_{20} \mathrm{O}_{12}$ & $300(100)$ & $\begin{array}{c}\text { quercetin } \\
\text { 3-O-glucoside }\end{array}$ & $\begin{array}{l}\text { Santos et al. } \\
\text { 2014; Zhao } \\
\text { et al. } 2017\end{array}$ \\
\hline 7 & 59.8 & $\begin{array}{l}212 \\
324\end{array}$ & 515.1202 & 515.1195 & 1.36 & $\mathrm{C}_{25} \mathrm{H}_{24} \mathrm{O}_{12}$ & $\begin{array}{c}179(100), 173 \\
(95), 353(50), \\
191(48), 335 \\
(25), 161(20), \\
135(13)\end{array}$ & $\begin{array}{l}\text { 3,4-di-O-caffeoylquinic } \\
\text { acid }\end{array}$ & $\begin{array}{l}\text { Heyman et } \\
\text { al. } 2015\end{array}$ \\
\hline 8 & 63.2 & $\begin{array}{l}214 \\
326\end{array}$ & 515.1201 & 515.1195 & 1.16 & $\mathrm{C}_{25} \mathrm{H}_{24} \mathrm{O}_{12}$ & $\begin{array}{c}191(100), 179 \\
(72), 353(29), \\
173(5)\end{array}$ & $\begin{array}{l}\text { 3,5-O-Dicaffeoylquinic } \\
\text { acid }\end{array}$ & $\begin{array}{l}\text { Clifford et } \\
\text { al. } 2005 .\end{array}$ \\
\hline 9 & 68.9 & $\begin{array}{l}254 \\
347\end{array}$ & 505.0992 & 505.0988 & 0.79 & $\mathrm{C}_{23} \mathrm{H}_{22} \mathrm{O}_{13}$ & $300(100)$ & $\begin{array}{c}\text { quercetin } \\
\text { 3-O-acetylgalactoside }\end{array}$ & $\begin{array}{c}\text { An et al. } \\
\text { 2013; Zhao } \\
\text { et al. } 2017 .\end{array}$ \\
\hline 10 & 70.8 & $\begin{array}{l}254 \\
349\end{array}$ & 505.0987 & 505.0988 & -0.20 & $\mathrm{C}_{23} \mathrm{H}_{22} \mathrm{O}_{13}$ & $300(100)$ & $\begin{array}{c}\text { quercetin } \\
\text { 3-O-acetylglucoside }\end{array}$ & $\begin{array}{c}\text { An et al. } \\
\text { 2013; Zhao } \\
\text { et al. } 2017 .\end{array}$ \\
\hline 11 & 90.6 & $\begin{array}{l}212 \\
326\end{array}$ & 515.1194 & 515.1195 & -0.19 & $\mathrm{C}_{25} \mathrm{H}_{24} \mathrm{O}_{12}$ & $\begin{array}{c}173(100), 179 \\
(93), 353(65), \\
191(33), 135 \\
(11)\end{array}$ & $\begin{array}{l}\text { 4,5-O-Dicaffeoylquinic } \\
\text { acid }\end{array}$ & $\begin{array}{l}\text { Clifford et } \\
\text { al. } 2005 .\end{array}$ \\
\hline
\end{tabular}


Seven phenolic acids derived from hydroxycinnamic acid were found and identified by UV and MS/MS fragmentation data. Peaks 1, 2, 3, 4, 7, 8 and 11 showed the UV spectra characteristic of hydroxycinnamic acids by means of two absorption bands at 212-217 $\mathrm{nm}$ and 322-326 $\mathrm{nm}$. Peak 3 was identified as 5-O-caffeoylquinic acid $(\mathrm{m} / \mathrm{z} 353)$, characterized by a unique $\mathrm{m} / \mathrm{z} 191$ fragment, indicating loss of the caffeoyl group, which yields a quinic acid residue $(\mathrm{m} / \mathrm{z} 191)$. Peak 1 refers to 3-O-caffeoylquinic acid isomer, which exhibits the same $\mathrm{m} / z 191$ fragment besides others: $m / z 179$ corresponding to the formed caffeic acid given the loss of quinic acid; and $\mathrm{m} / \mathrm{z}$ 135 , indicating loss of $\mathrm{CO}_{2}$ of caffeic acid. Peak 4 was identified as 4-O-caffeoylquinic acid isomer which exhibits the highest number of fragments: $\mathrm{m} / \mathrm{z} 191, \mathrm{~m} / \mathrm{z} 179, \mathrm{~m} / \mathrm{z} 135$ and $\mathrm{m} / \mathrm{z} 173$, which is relative to the loss of $\mathrm{H}_{2} \mathrm{O}$ from quinic acid. Peak $2(\mathrm{~m} / \mathrm{z} 179)$ was identified as caffeic acid. Peaks 7,8 and 11 are related to three different isomers of dicaffeoylquinic acid $(\mathrm{m} / \mathrm{z} 515)$. The difference between these isomers is the relative abundance of their fragments. Peak 7 was identified as 3,4-di-Ocaffeoylquinic acid. This molecular ion resulted in the following fragments: $m / z 179$, formed by loss of a quinic acid and a caffeoyl group; $m / z$ 191, caused by loss of two caffeoyl groups; $\mathrm{m} / \mathrm{z} 353$, corresponding to the caffeoylquinic acid formed by loss of one caffeoyl group; $m / z 335$, formed by loss of $\mathrm{H}_{2} \mathrm{O}$ of caffeoylquinic acid; $\mathrm{m} / z$ 161, relative to the loss of $\mathrm{H}_{2} \mathrm{O}$ of caffeic acid. Peak 8 refers to 3,5-di- $O$-caffeoylquinic acid isomer with fragments $m / z$ 191, $m / z 179, m / z 353$ and $m / z 173$. Peak 11 was identified as 4,5 -di- $O$-caffeoylquinic acid, characterized by the fragments $\mathrm{m} / \mathrm{z} 173, \mathrm{~m} / \mathrm{z}$ 179, $\mathrm{m} / \mathrm{z} 353, \mathrm{~m} / \mathrm{z} 191$ and $\mathrm{m} / \mathrm{z} 135$.

Peaks 5, 6, 9 and 10 showed the UV spectra characteristic of flavonols-3- $O$-hexoses on account of two absorption maxima at 247-349 and at 254 $\mathrm{nm}$. Peaks 5 and 6 were identified as quercetin 3-O-hexose $(\mathrm{m} / \mathrm{z} 463)$, which was characterized by a unique $\mathrm{m} / \mathrm{z} 300$ fragment indicating loss of one hexose. Peaks 9 and $10(\mathrm{~m} / z$ 505) showed the same fragmentation pattern of $\mathrm{m} / \mathrm{z} 300$, for which they were attributed to quercetin-3-O-acetylhexose. Peak 10 's attribution was only possible due to quercetin- 6"-O-acetyl-3-O-glucoside isolation by countercurrent chromatography and its analysis by UPLC MS-MS. As peak 9 has the same molecular mass and fragmentation as peak 10 , it was identified as quercetin-6" $O$-acetyl-3-O-galactoside. Fractions 18 and 19 obtained from countercurrent separation of methanolic fraction were submitted to NMR analysis. Fraction 18 was identified as a mixture of quercetin 3-O-glucoside and quercetin 3 - $O$-galactoside, whereas fraction 19 as quercetin 3-O-glucoside. Quercetin 3-O-glucoside isolation

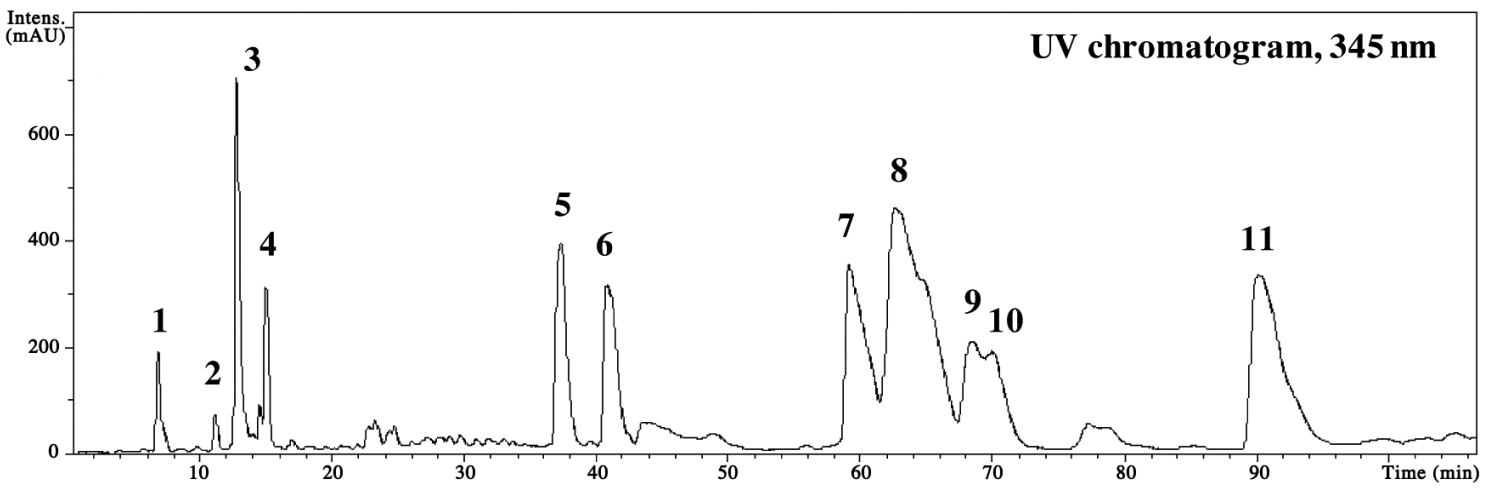

Figure 1 - UPLC-UV chromatogram at $\lambda 345 \mathrm{~nm}$ of the methanolic fraction from Ipomoea pes-caprae. Analytical conditions: stationary phase: $\mathrm{C}-18$ Zorbax column $(1.7 \mu \mathrm{m}, 2.1 \times 75 \mathrm{~mm}$, Phenomenex $)$; temperature: $40{ }^{\circ} \mathrm{C}$; mobile phase: $\mathrm{A}=$ ultra pure water containing $0.1 \%$ formic acid, $\mathrm{B}=$ acetonitrile containing $0.1 \%$ formic acid; flow rate: 0.25 $\mathrm{mL} \cdot \mathrm{min}^{-1}$; detection: $345 \mathrm{~nm}$; injection volume: $10 \mu \mathrm{L}$; solvent composition during analysis: $0-2 \mathrm{~min} 2.5 \% \mathrm{~B}, 2-25$ $\min 2.5$ to $9.5 \% \mathrm{~B}, 25-55 \min$ maintained at $9.5 \% \mathrm{~B}, 55-60 \min 9.5$ to $9.6 \% \mathrm{~B}, 60-85 \min 9.6$ to $11 \% \mathrm{~B}, 85-110$ $\min 11$ to $15 \% \mathrm{~B}, 110-140 \min 15$ to $25 \% \mathrm{~B}, 140-145 \min 25$ to $100 \% \mathrm{~B}, 145-150$ min kept at $100 \%$ B, $150-155$ min from 100 to $2.5 \% \mathrm{~B}, 155-160 \mathrm{~min} 2.5 \% \mathrm{~B}$. Peak numbering indicates the substances identified in the UPLC-MS analysis: 3- $O$-Caffeoylquinic acid (1), Caffeic acid (2), 5- $O$-Caffeoylquinic acid (3), 4-O-Caffeoylquinic acid (4), quercetin 3-O-galactoside (5), quercetin 3- $O$-glucoside (6), 3,4-di- $O$-Caffeoylquinic acid (7), 3,5- $O$-Dicaffeoylquinic acid (8), quercetin 3-O-acetylgalactoside (9), quercetin 3- $O$-acetylglucoside (10), 4,5-O-Dicaffeoylquinic acid (11). 
<smiles>C[C@@H]1CC(O)(C(=O)O)C[C@@H](OC(=O)/C=C/c2ccc(Br)c(O)c2)[C@@H]1C</smiles><smiles>COc1ccc(/C=C/C(=O)O)cc1O</smiles><smiles>C[C@H]1C[C@@H](C)C[C@@H](Cl)[C@H]1CC(=O)/C=C/c1ccc(O)c(O)c1</smiles><smiles>C[C@@H]1C(CO)OC(Oc2c(-c3ccc(O)c(O)c3)oc3cc(O)cc(O)c3c2=O)[C@H](C)[C@H]1O</smiles><smiles>CC(=O)C1(C)C[C@H](C)[C@H](OC(=O)/C=C/c2ccc(O)c(O)c2)[C@H](CC(=O)/C=C/c2ccc(O)c(O)c2)C1</smiles><smiles>CC(=O)[C@@]1(O)C[C@@H](CC(=O)/C=C/c2ccc(O)c(C)c2)[C@@H](C)[C@@H](OC(=O)/C=C/c2ccc(O)c(O)c2)C1</smiles><smiles>CC(=O)C(C)[C@H]1O[C@H](Oc2c(-c3ccc(O)c(O)c3)oc3cc(O)cc(C)c3c2=O)[C@H](C)[C@H](C)[C@H]1I</smiles><smiles>[X]c1ccc(/C=C/C(=O)O[C@H]2C[C@](C)(C(=O)O)C[C@@H](O)[C@H]2OC(=O)/C=C/c2ccc(O)c(O)c2)cc1O</smiles><smiles>Cc1cc(-c2oc3cc(O)cc(O)c3c(=O)c2OC2OC(CO)[C@@H](O)[C@H](F)[C@H]2C)ccc1O</smiles><smiles>CN[C@H]1[C@H](O)[C@@H](C(C)C(C)=O)OC(Oc2c(-c3ccc(OC)c(O)c3)oc3cc(O)cc(O)c3c2=O)[C@@H]1C</smiles>

Figure 2 - a- k. Substances identified in the methanolic fraction from Ipomoea pes-caprae - a. 3-O-Caffeoylquinic acid; b. Caffeic acid; c. 5-O-Caffeoylquinic acid; d. 4-O-Caffeoylquinic acid; e. quercetin 3-O-galactoside; f. quercetin 3-O-glucoside; g. 3,4-di- $O$-Caffeoylquinic acid; h. 3,5-O-Dicaffeoylquinic acid; i. quercetin 3-O-acetylgalactoside; j. quercetin 3-O-acetylglucoside; k. 4,5-O-Dicaffeoylquinic acid.

and UPLC-MS-MS analysis confirmed the hexoxide type of peaks 5 and 6 (Tab. 1).

\section{Hemodynamic evaluation}

Intravenous infusion of the extract, the methanolic fraction, the fraction 10 (PIEA-M-1-10Compound 1) and the fraction 18 (PIEA-M-1-18Compounds $2 \mathrm{a}$ and $2 \mathrm{~b}$ ) were performed in normotensive rats to investigate changes in arterial blood pressure. Although fraction 18 contained a quercetin-3-O-glycoside mixture, this fraction was used in hemodynamic test because these flavonols have the same aglycone and fraction 19 had not sufficient quantity to be used for testing.
The effective dose (30 mg. $\mathrm{kg}^{-1}$ ) was chosen for being the middle value in the concentration logarithmic graph (from $1 \mathrm{mg} \cdot \mathrm{kg}^{-1}$ to $300 \mathrm{mg} \cdot \mathrm{kg}^{-1}$ of animal). This concentration allowed the evaluation whether the plant extract has any activity without sacrificing many rats.

After extract administration, all parameters analyzed were significantly reduced when compared to initial pressure and control (DMSO) in normotensive rats (Fig. 3a-c). A comparison between the initial and the extract infusion pressure showed systolic blood pressure (SBP) decreased by $67.7 \mathrm{mmHg}$, diastolic blood pressure (DBP) decreased by $69.6 \mathrm{mmHg}$ and mean 

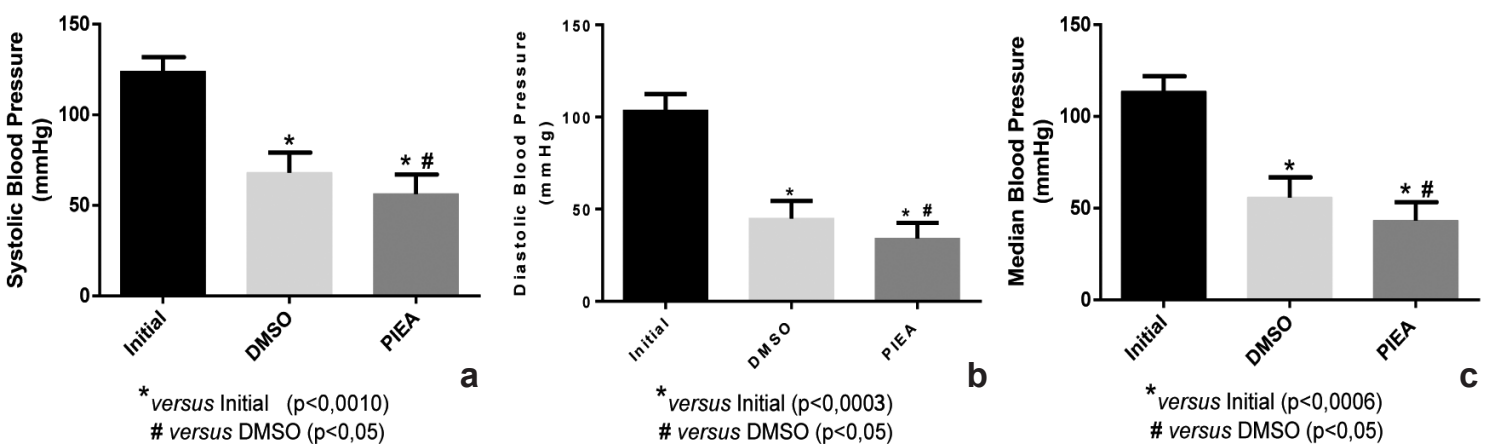

Figure 3 - a-c. Effects of Ipomoea pes-caprae extract $\left(30 \mathrm{mg} \cdot \mathrm{kg}^{-1}\right)$ on blood pressure of normotensive Wistar rats - a. systolic blood pressure (SBP); b. diastolic blood pressure (DBP); c. mean arterial pressure (MBP). Values are expressed as mean of five experiments.

arterial pressure (MBP) decreased by $70.4 \mathrm{mmHg}$. The control (DMSO) and the initial pressure comparison showed a lower reduction in which SBP decreased by $55.9 \mathrm{mmHg}$, DBP decreased by $58.6 \mathrm{mmHg}$ and MBP decreased by 57.8 $\mathrm{mmHg}$. The reduction induced after application of DMSO was already expected once this solvent has hypotensive effect caused by histamine release (Santis \& Prata 2009). The differences between the changes in blood pressure caused by DMSO and by the extract indicates a statistically significant $(p<0.05)$ hypotensive effect of the hydroalcoholic extract. The chemical profile obtained for the extract suggests its effect could be caused by phenolic compounds such as flavonoids, which are recognized for their cardiovascular and vasodilatory activities. For instance, quercetin is a flavonoid which reduces high blood pressure. In an in vivo test with hypertensive mice using $10 \mathrm{mg} \cdot \mathrm{kg}^{-1}$ of quercetin daily for five weeks, has shown a reduction of systolic, diastolic and medium blood pressure (Duarte et al. 2001; Guerrero et al. 2002; Oboh et al. 2012). Besides, phenolic compounds are responsible for the hypotensive activity of other Ipomoea species. For example, a polyphenol rich extract of Ipomoea reniformis exhibiting hypotensive activity (Jabeen \& Aslam 2013) and also Ipomoea batata with verified hypotensive effect, in part due to its inhibitory activity of angiotensin converting enzyme of its caffeoylquinic acids (Ishiguro et al. 2007).

After administration of methanolic fraction, a significant reduction of all analyzed parameters was verified in comparison with initial pressure and control (Fig. 4a-c). Compared with initial pressure, the methanolic fraction infusion reduced SBP by $74.5 \mathrm{mmHg}$, DBP decreased by 72.9 $\mathrm{mmHg}$ and MBP decreased by $73.6 \mathrm{mmHg}$. DMSO (control) caused a lower reduction than the sample, suggesting the hypotensive effects of the tested sample. DMSO decreased SBP by
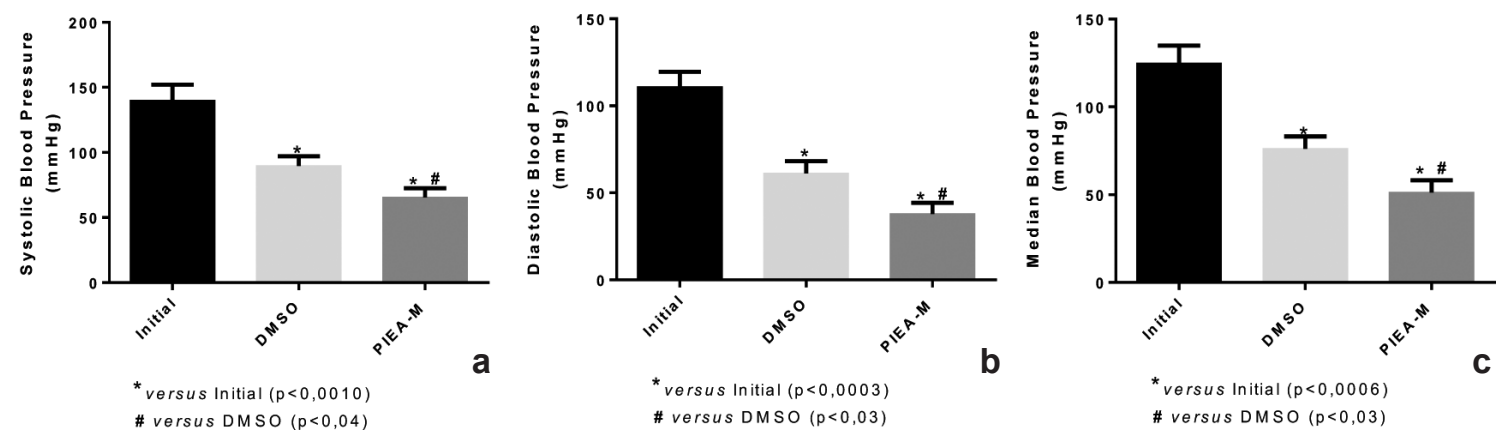

Figure 4 - a-c. Effects of the methanolic fraction $\left(30 \mathrm{mg} \cdot \mathrm{kg}^{-1}\right)$ on blood pressure of normotensive Wistar rats - a. systolic blood pressure (SBP); b. diastolic blood pressure (DBP); c. mean arterial pressure (MBP). Values are expressed as mean of five experiments. 
$50.1 \mathrm{mmHg}$, DBP decreased by $49.6 \mathrm{mmHg}$ and MBP by $48.6 \mathrm{mmHg}$. The statistical analysis (p $<0.05$ ) confirmed the hypotensive activity of the methanolic fraction.

Fraction 10 administration also significantly decreased SBP by $87.6 \mathrm{mmHg}$, DBP by 82.8 $\mathrm{mmHg}$ and MBP by $88.2 \mathrm{mmHg}$. DMSO caused a lower reduction in comparison to the sample: SBP was reduced by $50.6 \mathrm{mmHg}$, DBP decreased by $60.2 \mathrm{mmHg}$ and MBP decreased by $58.4 \mathrm{mmHg}$. The statistical analysis $(\mathrm{p}<0.05)$ of the maximum effect caused by DMSO and by the sample showed the hypotensive effect of the compound present in fraction 10 (Fig. 5a-c). This is the first report of hypotensive activity of Quercetin 6"- $O$-acetyl-3$O$-glucoside.
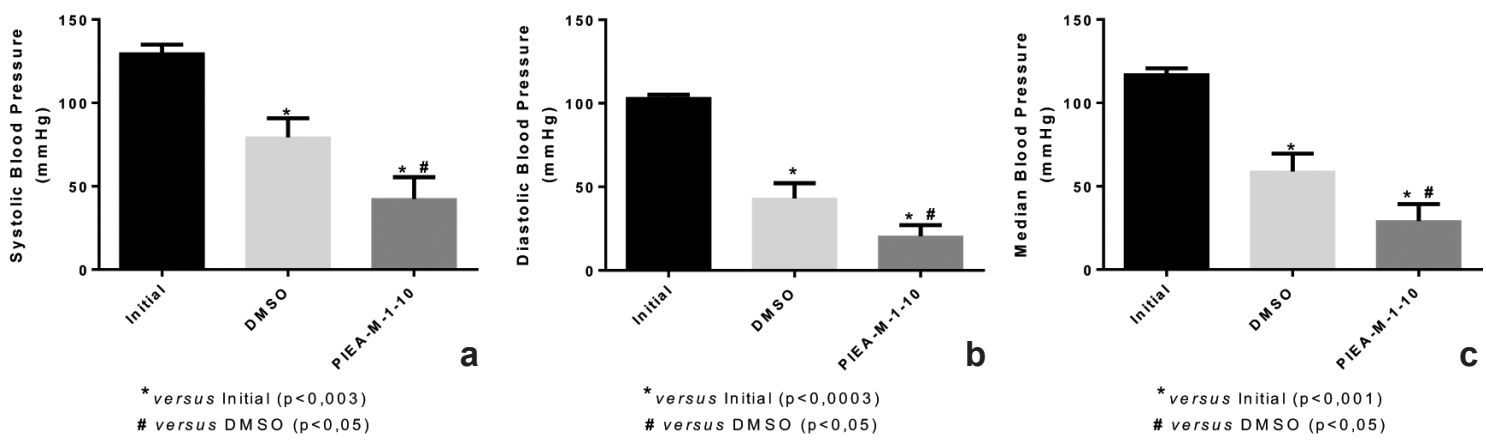

Figure 5 - a-c. Effects of the fraction $10\left(30 \mathrm{mg} \cdot \mathrm{kg}^{-1}\right)$ on blood pressure of normotensive Wistar rats $-\mathrm{a}$. systolic blood pressure (SBP); b. diastolic blood pressure (DBP); c. mean arterial pressure (MBP). Values are expressed as mean of three experiments.

Comparing the reduction of pressure caused by administration of the control and fraction 18 , we observed the sample produce a greater drop at initial blood pressure. The application of fraction 18 reduced SBP by 68.8 $\mathrm{mmHg}$, DBP by $70.6 \mathrm{mmHg}$ and MBP by 71.6 $\mathrm{mmHg}$. While, DMSO promoted a decrease of $48.5 \mathrm{mmHg}$ in SBP, $57 \mathrm{mmHg}$ in DBP and 53.7 $\mathrm{mmHg}$ in MBP (Fig. 6a-c). Although there was not statistically significance between DMSO and sample values, a reduction of $10 \mathrm{mmHg}$ in rat pressure is quite significant and, in this case, discounting the effect of DMSO, the sample generated a reduction of $20.3 \mathrm{mmHg}$ in SBP, $13.6 \mathrm{mmHg}$ in DBP and $17.9 \mathrm{mmHg}$ in MBP. The flavonoids quercetin 3-O-glucoside and quercetin 3-O-galactoside, which are present in fraction 18, have already had their hypotensive activity reported in the literature. In an in vitro study, flavonoids exhibited inhibitory activity against the angiotensin conversor enzyme (ACE) (Balasuriya \& Rupasinghe 2012).
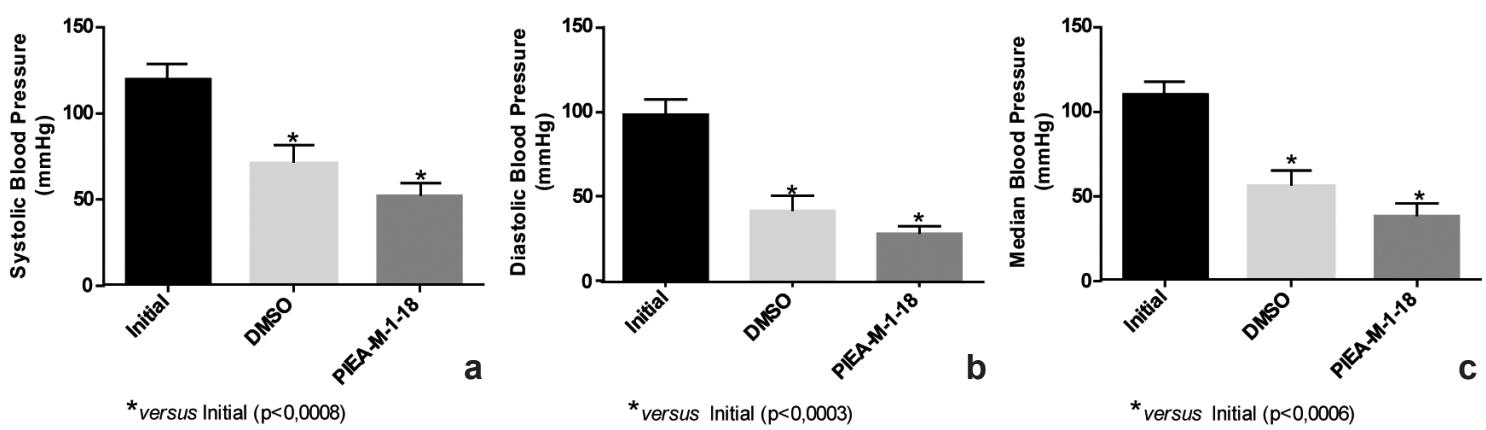

Figure 6 - a-c. Effects of the fraction $18\left(30 \mathrm{mg} \cdot \mathrm{kg}^{-1}\right)$ on blood pressure of normotensive Wistar rats - a. systolic blood pressure (SBP); b. diastolic blood pressure (DBP); c. mean arterial pressure (MBP). The values are expressed as mean of three experiments. 
The Rota-Rod test revealed the extract PIEA and PIEA-M impair locomotor activity of the mices at 15 and $30 \mathrm{~min}$ after administration (Fig. 7). Although the number of falls decreased in-between each evaluation, the results were statistically significant when compared to the control group. On the other hand, at 60 and $120 \mathrm{~min}$, the extracts were unable to cause significant effects on motor coordination, while diazepam maintained its effects. It is worth noting that PIEA and PIEA-M had not shown statistical difference.

Phenolic compounds, such as flavonoids and hydroxycinnamic derivatives, are known to possess efect on the central nervous system, displaying neuroprotective and sedative properties (Johnston 2015; Silva et al. 2015; German-Ponciano et al. 2018). Thus, mices motor incoordination could be related to beta adrenergic inhibition, which promotes decrease in psychomotor function. For example, propranolol, a beta blocker used in hypertension, causes motor deficiency (Broadhurst 1980). Flavonoids have some antihypertensive mechanisms already confirmed, such as endothelin-1 inhibition, a strong vasoconstrictor agent, and stimulation of nitric oxide production, a potent vasodilator through induction of nitric oxide synthase, an endothelial enzyme. This class of compounds also reduces angiotensin II levels through inhibitory activity against angiotensin converting enzyme

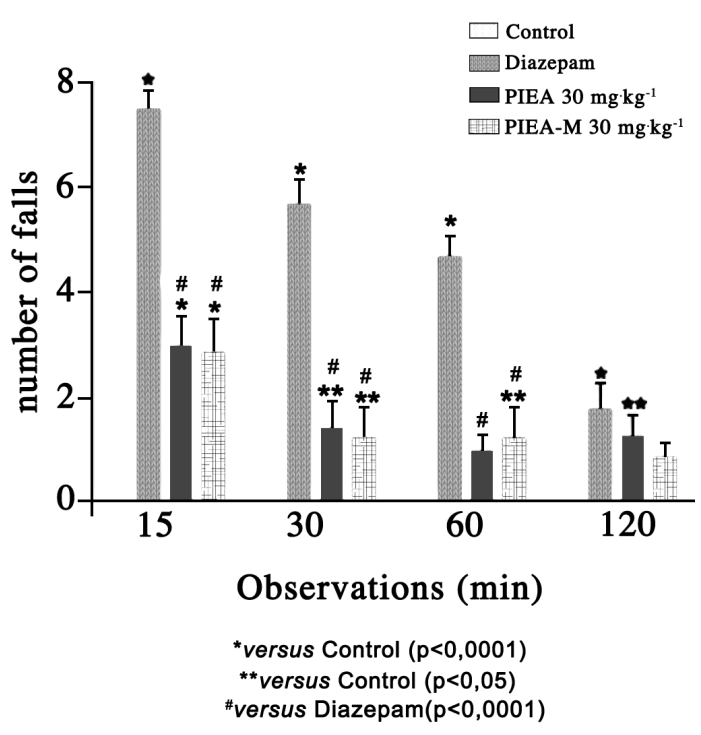

Figure 7 - Effects of extract and methanolic fraction of Ipomoea pes-caprae on Swiss mice in Rota-Rod test. Values are expressed as mean of ten experiments.
(ACE), and increases hypotensive action of bradykinin (B2 receptor agonist), which releases nitric oxide and prostacyclin and contributes to blood pressure control (Loizzo et al. 2008; Loke et al. 2008; Balasuriya \& Rupasinghe 2012). Besides, flavonoids also show inhibitory effect on phosphodiesterase, increasing cyclic adenosine monophosphate (cAMP), thus contributing to vasodilatation (Duarte et al. 1993; Röhrig et al. 2017). Phenolic compounds and flavonoids present in these samples are classes with high antioxidant capacity, which is fundamental for controlling physiological balance and inhibiting oxidative stress. Previous studies indicate increased oxidative stress can contribute to hypertension (Touyz \& Schiffrin 2004; Silva et al. 2015; German-Ponciano et al. 2018).

With the results obtained in this study, it was possible to verify that phenolic compounds are the substances responsible for the anti-hypertensive activity empirically attributed to Ipomoea pescaprae.

\section{Acknowledgements}

The authors are grateful to FAPERJ for financial support and to CAPES process $n$. 31033016013PO for scholarships.

\section{References}

Agrawal PK (1989) Carbon-13 NMR of flavonoids. Elsevier, Amsterdam. 564p.

An H, Wang H, Lan Y, Hashi Y \& Chen S (2013) Simultaneous qualitative and quantitative analysis of phenolic acids and flavonoids for the quality control of Apocynum venetum L. leaves by HPLCDAD-ESI-IT-TOF-MS and HPLC-DAD. Journal of Pharmaceutical and Biomedical Analysis 85: 295-304.

Balasuriya N \& Rupasinghe HPV (2012)Antihypertensive properties of flavonoid-rich apple peel extract. Food Chemistry 135: 2320-2325.

Banerjee D, Hazra AK, Seal T, Sur T, Bhattacharya D, Ray J, Mukherjee A \& Mukherjee B (2013) Antioxidant and anti-inflammatory activities of different solvent extracts and isolated compounds of Ipomoea pes-caprae (L) Sweet of Sunderban Mangrove eco-complex. Asian Journal of Chemistry 25: 4997-5000.

Barni ST, Filho VC \& Couto AG (2009) Chemical and technological characterization of Ipomoea pes-caprae (L.) R. Br., Convolvulaceae, leaves, branches and entire plant as a pharmaceutical raw material. Revista Brasileira de Farmacognosia 19: 865-870. 
Berlinck RGS, Borges WS, Scotti MT \& Vieira PC (2017) The chemistry of natural products in Brazil in the XXI century. Química Nova 40: 706-710.

Berthod A \& Carda-Broch S (2004) Determination of liquid-liquid partition coefficients by separation methods. Journal of Chromatography A 1037: 3-14.

Broadhurst AD (1980) The effect of propranolol on human psychomotor performance. Aviation, Space, and Environmental Medicine 2: 176-179.

Clifford MN, Knight S \& Kuhnert N (2005) Discriminating between the six isomers of dicaffeoylquinic acid by LC-MS ${ }^{n}$. Journal of Agricultural and Food Chemistry 53: 3821-3832.

Deepralard K, Kawanishi K, Moriyasu M, Pengsuparp T \& Suttisril R (2009) Flavonoid glycosides from the leaves of Uvaria rufa with advanced glycation end-products inhibitory activity. Thai Journal of Pharmaceutical Sciences 33: 84-90.

Duarte J, Vizcaíno FP, Utrilla P, Jiménez J, Tamargo J \& Zarzuelo A(1993) Vasodilatory effects of flavonoids in rat aortic smooth muscle. Structure-activity relationships. General Pharmacology 24: 857-862.

Duarte J, Pérez-Palencia R, Vargas F, Ocete MA, Pérez-Vizcaino F, Zarzuelo A \& Tamargo J (2001) Antihypertensive effects of the flavonoid quercetin in spontaneously hypertensive rats. British Journal of Pharmacology 133: 117-124.

Escobedo-Martínez C, Cruz-Morales S, Fragoso-Serrano, M, Rahman MM, Gibbons S \& Pereda-Miranda R (2010) Characterization of a xylose containing oligosaccharide, an inhibitor of multidrug resistance in Staphylococcus aureus, from Ipomoea pescaprae. Phytochemistry 71: 1796-1801.

Fabricant DS \& Farnsworth NR (2001) The value of plants used in traditional medicine for drug discovery. Environ Health Perspects 109: 69-75.

German-Ponciano LJ, Rosas-Sánchez GU, RivadeneyraDomínguez E \& Rodríguez-Landa JF (2018) Advances in the preclinical study of some flavonoids as potential antidepressant agents. Scientifica 2018: 2963565.

Guerrero MF, Puebla P, Carrón R, Martín ML, Arteaga L \& Román LS (2002) Assessment of the antihypertensive and vasodilator effects of ethanolic extracts of some Colombian medicinal plants. Journal of Ethnopharmacology 80: 37-42.

Heyman HM, Senejoux F, Seibert I, Klimkait T, Maharaj VJ \& Meyer JJM (2015) Identification of anti-HIV active dicaffeoylquinic- and tricaffeoylquinic acids in Helichrysum populifolium by NMR-based metabolomic guied fractionation. Fitoterapia 103: 155-164.

Ishiguro K, Yoshimoto M, Tsubata M \& Takagaki K (2007) Hypotensive effect of sweet potato tops. Nippon Shokuhin Kagaku Kogaku Kaishi 54: 45-49.

Jabeen Q \& Aslam N (2013) Hypotensive, Angiotensin converting Enzyme (ACE) inhibitory and diuretic activities of the aqueous-methanol extract of Ipomoea reniformis. Iranian Journal of Pharmaceutical Research 12: 769-776.

Jaiswal R, Müller H, Müller A, Karar MGE \& Kuhnert N (2014) Identification and characterization of chlorogenic acids, chlorogenic acid glycosides and flavonoids from Lonicera henryi L. (Caprifoliaceae) leaves by LC-MS ${ }^{\mathrm{n}}$. Phytochemistry 30: 1-12.

Johnston GAR (2015) Flavonoid nutraceuticals and ionotropic receptors for the inhibitory neurotransmitter GABA. Neurochemistry International 89: 120-125.

Kannel WB (2000) Risk stratification in hypertension: new insights from the Framingham. American Journal of Hypertension 13: 3S-10S.

Krogh R, Kroth R, Berti C, Madeira AO, Souza MM, Cechinel-Filho V, Delle-Monache F \& Yunes RA(1999) Isolation and identification of compounds with antinociceptive action from Ipomoea pes-caprae (L.) R. Br. Die Pharmazie 54: 464-466.

Larson AJ, Symons JD \& Jalili T (2010) Quercetin: a treatment for hypertension? - Review of efficacy and mechanisms. Pharmaceuticals 3: 237- 250.

Loizzo MR, Tundis R, Menichini F, Statti GA \& Menichini F (2008) Hypotensive natural products: current status. Mini-Reviews in Medicinal Chemistry 8: 828-855.

Loke WM, Hodgson JM, Proudfoot JM, McKinley AJ, Puddey IB \& Croft KD (2008) Pure dietary flavonoids quercetin and (-)-epicatechin augment nitric oxide products and reduce endothelin-1 acutely in healthy men. The American Journal of Clinical Nutrition 88: 1018-1025.

Lorenzi H \& Matos FJA (2002) Plantas medicinais no Brasil: nativas e exóticas. Instituto Plantarum, Nova Odessa. 182p.

Miryeganeh M, Takayama K, Tateishi Y \& Kajita T (2014) Long-distance dispersal by sea-drifted seeds has maintained the global distribution of Ipomoea pes-caprae subsp. brasiliensis (Convolvulaceae). PlosOne 9: e91836.

Ncube EN, Mhlongo MI, Piater LA, Steenkamp PA, Dubery IA \& Madala NE (2014) Analyses of chlorogenic acids and related cinnamic acid derivatives from Nicotiana tabacum tissues with the aid of UPLC-QTOF-MS/MS based on the in-source collision-induced dissociation method. Chemistry Central Journal 8: 66.

Newman DJ \& Cragg GM (2016) Natural products as sources of new erugs from 1981 to 2014. Journal of Natural Products 79: 629-661.

Oboh G, Ademiluyi AO, Akinyemi AJ, Henle T, Saliu JA \& Schwarzenbolz U (2012) Inhibitory effect of polyphenol-rich extracts of jute leaf (Corchorus olitorius) on key enzyme linked to type 2 diabetes ( $\alpha$-amylase and $\alpha$-glucosidase) and hypertension (angiotensin I converting) in vitro. Journal of Functional Foods 4: 450-458.

Pereda-Miranda R, Escalante-Sánchez E \& EscobedoMartínez C (2005) Characterization of lipophilic pentasaccharides from beach morning glory 
(Ipomoea pes-caprae). Journal of Natural Products 68: 226-230.

Röhrig T, Pacjuk O, Hernández-Huguet S, Körner J, Scherer K \& Richling E (2017) Inhibition of cyclic adenosine monophosphate-specific phosphodiesterase by various food plant-derived phytotherapeutic agents. Medicines 4: 80.

Santis GC \& Prata KL (2009) Cryopreservation of hematopoietic progenitor cells. Medicina42: 36-47.

Santos J, Oliveira MBPP, Ibáñez E \& Herrero M (2014) Phenolic profile evolution of different ready-toeat baby-leaf vegetables during storage. Journal of Chromatography A 1327: 118-131.

Sharmin S, Zohora FT, Tareq FS, Islam SN, Hasan CM \& Ahsan M (2013) Phytochemical and biological investigation on Ipomoea pes caprae (L.) R. Br. American Journal of Pharmtech Research 3: 902-912.

Silva T, Bravo J, Summavielle T, Remião F, Pérez Z, Gil C, Martínez A \& Borges F (2015) Biology-oriented development of novel lipophilic antioxidants with neuroprotective activity. RSC Advances 5: 1580015811.

Souza MM, Madeira A, Berti C, Krogh R, Yunes R, Krogh R, Yunes RA \& Cechinel-Filho V (2000) Antinociceptive properties of the methanolic extract obtained from Ipomoea pes-caprae (L.) R. Br. Journal of Ethnopharmacology 69: 85-90.

Teramachi F, Koyano T, Kowithayakorn T, Hayashi M, Komiyama M, Komiyama K \& Ishibashi M (2005)
Collagenase inhibitory quinic acid esters from Ipomoea pes caprae. Journal of Ethnopharmacology 68: 794-796.

Touyz RM \& Schiffrin EL (2004) Reactive oxygen species in vascular biology: implications in hypertension. Histochemistry and Cell Biology 122: 339-352.

Viegas Jr C \& Bolzani VS (2006) The natural products and the modern medicinal chemistry. Química Nova 29: 326-337.

Wasuwat S (1970) Extract of Ipomoea pes-caprae (Convolvulaceae) antagonistic to histamine and jelly-fish poison. Nature 225: 758.

World Health Organization (2013) A comprehensive report on Hypertension. Available at $<$ http://www. who.int/>. Access on 29 May 2018.

World Health Organization (2017) World health statistics 2017: monitoring health for the SDGs, sustainable development goals. Available at $<\mathrm{http}$ ://www.who. int/>. Access 29 May 2018.

Yu BW, Luo JG, Wang JS, Zhang DM, Yu SS \& Kong LY (2011) Pentasaccharide resin glycosides from Ipomoea pes-caprae. Journal of Natural Products 74: 620-628.

Zhao Y, Wu X, Yu L \& Chen P (2017) Retention of polyphenols in blueberries (Vaccinium corymbosum) after different cooking methods, using UHPLCDAD-MS based metabolomics. Journal of Food Composition and Analysis 56: 55-66. 